$$
\begin{array}{r|r:r}
-\mathrm{CF}_{2}-\mathrm{CF}_{2}-\mathrm{N}-\mathrm{O}-\mathrm{CF}_{2}-\mathrm{CF}_{2}-\mathrm{N}-\mathrm{O}-\longrightarrow \\
1 & \mathrm{CF}_{3} & \\
\mathrm{CF}_{3} & \mathrm{CF}_{3} \mathrm{~N}: \mathrm{CF}_{2}+\mathrm{COF}_{2}
\end{array}
$$

This appears to be the first example of an $\mathrm{N}: \mathrm{O}$ group acting like $\mathrm{C}: \mathrm{C}$ in copolymerization, although it has beon shown ${ }^{2}$ that free radical addition to $\mathrm{N}: \mathrm{O}$ can oceur.

$$
\begin{aligned}
& \text { D. A. BARR } \\
& \text { R. N. HASZELDINE }
\end{aligned}
$$

University Chemical Laboratory, Cambridge.

${ }^{1}$ Haszeldine, R. N., Nature, 168, 1028 (1951); J. Chem. Soc., 2075 (1953).

${ }^{2}$ Haszeldine, R. N., and Jander, J., J. Chem. Soc., 4172 (1953); 696, 912,919 (1954); Naturwiss., 22, 579 (1953).

\title{
Dimerization Reactions in Sunlight
}

THE investigations previously reported ${ }^{1}$ have been continued and I wish to put the following facts on record. The photo-experiments mentioned below have been carried out in a sealed 'Pyrex' glass tube (Schlenk tub ${ }^{2}$ ) in an atmosphere of dry carbon dioxide; in all cases the dark experiments were negative.

It seems possible that the $2-3$ bond in benzothiophene/1-dioxide ${ }^{1}$ would undergo an analogous photo-dimerization reaction, under comparable conditions, typical of the similarly situated bond in indone derivatives, for example, 2-methyl-3-phenylindone ${ }^{3}$. This is indeed the case. When a benzene solution of (I) is exposed to sunlight for three days (July), it forms the difficultly soluble colourless photodimer, melting point $296^{\circ}$, from acetic acid (78 per cent yield) (found: $\mathrm{C}, 57 \cdot 6 ; \mathrm{H}, 3 \cdot 6 ; \mathrm{S}, 19 \cdot 1$. $\mathrm{C}_{18} \mathrm{H}_{12} \mathrm{O}_{4} \mathrm{~S}_{2}$ requires $\mathrm{C}, 57 \cdot 8 ; \mathrm{H}, 3.6 ; \mathrm{S}, 19 \cdot 2$ per cent). The photo-dimer, believed to be (III $a$ ), sublimes readily at $300^{\circ}$ under reduced pressure; a fact which excludes the possibility that it could be regarded as a Diels-Alder dimerization adduct (II) ${ }^{4}$.<smiles>O=S1c2cccc3cccc(c23)S1=O</smiles>

(I)

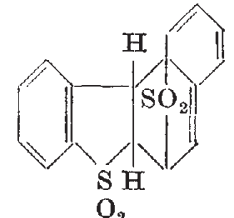

(II) (III $a, R=\mathrm{H}$; III $b, R=\mathrm{CH}_{3}$ )

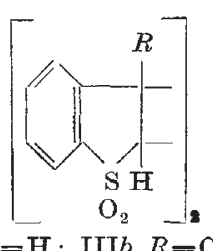

Similarly, 3-methylbenzothiophene 1-dioxide undergoes a photo-dimerization reaction when its benzene solution is exposed to sunlight for five days (January) to give the difficultly soluble colourless photo-dimer (IIIb), melting point $312^{\circ}$ (82 per cent yield).

A detailed report of this work will be published elsewhere.

Chemistry Department,

Faculty of Science,

Cairo University. Jan. 24.

Mustafa, Nature 163,856 (1948); 166, 108 (1950). Schönberg and Mustafa, Nature, 153, 195 (1944); 160, 401 (1947). Mustafa and Islam, J. Chem. Soc., 81 (1949).

Schlenk and Thal, Ber., 46, 2840 (1913).

- De Fazi, Gazz. chim. ital., 54, 58, 1000 (1924). Cf. also, Mustafa, Chem. Rev., 51, 1 (1952).

- Bordwell, McKellin and Babcock, J. Amer. Chem. Soc., 73, 5566 (1951).
Inactivation of Phage due to Assimilated Phosphorus-32 and the Recovery of Host Cells

From experiments carried out by other authors ${ }^{2}$, who have exposed to ultra-violet light and to X-rays bacteria infected with different types of phages $(T 2$, $T 7$ ), it has been possible to obtain a general picture of the changes which take place during the latent period, from infection to the lysis of the host cells. It was found, in agreement also with other types of experiments, that phage $T 2$ begins to multiply only about 7-9 min. after infection. During this period the particle is not infectious and is responsible for the changes in the host cell which lead to the synthesis of new virus. Study of this early period might thus furnish important information about the rela. tionships established between virus and host cell.

To this end we decided to study the inactivation of the phage $B M$ (active on $B$. megatherium) strongly labelled with phosphorus-32, after its penetration into unlabelled cells suspended in a non-radioactive medium. A suitable freezing technique enabled us to stop the cellular metabolism at known times after infection. Our aims were to find : $(a)$ possible variations in the rate of inactivation of radioactive phage before and after its penetration into the cell; (b) possible variations in the rate of inactivation as a function of the time elapsed from the adsorption to the lysis of the host (about twenty minutes); (c) a possible recovery of the cell following inactivation of the phage after its penetration. For details of the technique of freezing and of preparation of the radioactive phage, we refer to previous publications ${ }^{2,3}$.

Repeated controls have shown that the frozen cells of $B$. megatherium survive completely this treatment. In order to measure the rate of inactivation of the radioactive phage within the cell, we chose a low infection ratio $(0 \cdot 2$ phage per cell), so as practically to eliminate multiple events. The infection mixture was prepared so as to ensure an adsorption of 50 per cent of the phage in 1 min.; after this time, the mixture was diluted in antiphage horse serum so as to stop adsorption and inactivate the unadsorbed phage, the concentration and strength of the serum being such as to cause inactivation of 99 per cent of the free phage in 1 min. The mixture was then diluted in broth and aerated in a suitable vessel from which samples could be taken quickly every 30 sec. and immediately frozen. In this way we obtained cells infected almost simultaneously in which the development of the radioactive phage was arrested at known times; afterwards the frozen samples were tested periodically for inactivation of radioactive intracellular phage up to $\mathbf{4 0}$ days.

In order to study cell recovery following the penetration and inactivation of the radioactive phage, we used infection ratios of either 1 or 3 ; the samples were frozen 2 or $4 \mathrm{~min}$. after infection, and tested on subsequent days by colony counts to ascertain the number of recovered cells.

The inactivation curves of the radioactive intracellular phage are quite similar for the first $5 \mathrm{~min}$. after infection. This result was obtained consistently in four experiments, during which this interval was examined thoroughly every 30 or 60 sec. The average value of the inactivation-rate of the radioactive intracellular phage is $k=6 \cdot 0$ (Fig. 1), a value significantly different from, and some 40 per cent less than, the inactivation-rate of the free frozen phage $\left(k^{\prime}=9 \cdot 3\right.$ (see ref. 3$)$ ). We have examined the behaviour of the inactivation-rate after the fifth 